Dr JASMINA MILANOVIĆ, viši naučni saradnik

Institut za savremenu istoriju

Beograd, Republika Srbija

jasmina.mil17@gmail.com

originalan naučni rad

UDK: 364-54-058.862:061.2(497.11)"1904/1941"

primljeno: 31. januar 2018.

364(497.11)"1904/1941"

prihvaćeno: 16 . maj 2018.

https://doi.org/10.29362/ist20veka.2018.2.mil.37-54

\title{
MATERINSKO UDRUŽENJE - HUMANI I SOCIJALNI ASPEKTI DELOVANJA 1904-1941.*
}

APSTRAKT: Socijalna politika u Kneževini i Kraljevini Srbiji nije bila regulisana na državnom nivou, već je staranje o napuštenoj deci, nemoćnima $i$ starima bilo briga opštinskih i okružnih vlasti. Prvo privremeno prihvatilište za decu - ratnu siročad stvoreno je posle srpsko-turskih ratova 1877, ali je briga o ovoj deci vrlo brzo prešla u ruke Ženskog društva. Još jedan dom je osnovan 1881. godine, ali su u njega primana deca starija od pet godina. Najveći procenat smrtnosti dece je bio upravo u grupi odojčadi i dece do 5 godine, pa je zato stvaranje Materinskog udruženja 1904. godine predstavljalo prekretnicu $u$ zdravstvenoj i socijalnoj nezi i zbrinjavanju napuštene dece i siročadi. Zahvaljujući posvećenom radu prve predsednice udruženja Sare Karamarković i potpredsednice dr Drage Ljočić, rezultati su bili vidljivi već u prvim godinama delovanja.

KLJUČNE REČI: Materinsko udruženje, Sara Karamarković, Draga Ljočić, socijalna politika, Dom za nahočad, Dom za odojčad

\section{Briga o napuštenoj deci - državna ili građanska dužnost?}

Socijalna politika Kneževine i Kraljevine Srbije nije bila organizovana na državnom nivou, nije postojalo ministarstvo, čak ni odeljenje pri nekom ministarstvu koje bi se sistematski bavilo socijalnim pitanjima. Briga za siromašne, bolesne, napuštene svedena je na pojedinačne akte milosrđa, a o napuštenoj deci su bile dužne da se staraju opštinske vlasti. Prva organizovana državna akcija po ovom pitanju bilo je prikupljanje ratne siročadi posle srpsko-turskih ratova 1876-1878. i njihovo zbrinjavanje za koje je zaduženo Ministarstvo prosvete. Posle dve godine rada privremenog doma nazvanog Sirotinjski zavod, osnovanog 1878. godine, ministarstvo se obratilo za pomoć Ženskom društvu.

\footnotetext{
${ }^{*}$ Rad je deo projekta Konflikti i krize: saradnja i razvoj u Srbiji i regionu u 19. i 20. veku (47030) koji finansira Ministarstvo prosvete, nauke i tehnološkog razvoja Republike Srbije.
} 
Nakon detaljnih pregovora sa predsednicom Katarinom Milovuk i dobijanja saglasnosti uprave društva, ministar je 2. septembra 1881. potpisao akt o uslovima pod kojim će se preuzeti briga o toj deci. ${ }^{1}$ Početkom 1880. godine u Beogradu je stvoreno i Društvo za pomaganje i vaspitanje sirotne i napuštene dece čiji je cilj bio da pomogne svoj napuštenoj deci, a ne samo ratnoj siročadi. Već 1. februara 1881. ovo društvo je osnovalo svoj Sirotinjski zavod u manastiru Rakovica. U prvom trenutku primljeno je 9 učenika i zaposlen jedan učitelj. Društvo je plaćalo učitelja i nabavljalo odeću za decu, dok im je manastir obezbeđivao stan, hranu i ogrev. ${ }^{2}$ Od 1887. ovo društvo je otpočelo zidanje posebne zgrade za Dom sirotne dece, čija je izgradnja završena 1892. godine. U Dom, međutim, nisu primana deca mlađa od 7 godina, što znači da napuštena odojčad i deca do pet godina, upravo ona koja su bila najugroženija, i dalje nisu bila zbrinuta.

Početkom 20. veka Kraljevina Srbija je bila suočena sa, naročito po gradovima, čestim slučajevima napuštene dece ili dece koja su ostala bez roditelja, a bilo je i onih koji su odbegli od kuće u potrazi za boljim životom. Ova deca su često ostavljana na milost pojedinaca, dok su ona najmlađa imala malo šansi da prežive. Pojedine porodice koje su u toku epidemija gubile svoju decu, vrlo su lako i brzo mogle da usvoje siročiće. Međutim, domovi koji bi mogli da okupe ovu napuštenu decu, a potom ih daju na usvajanje, nisu postojali. Poražavajući su podaci koji se odnose na prosečan vek žena početkom 20 . veka. U varošima Srbije su na 1.000 muškaraca dolazile svega 752 žene, dok je na selu situacija bila nešto bolja. Posebno su bile ugrožene samohrane majke i razvedene žene, čiji je prosečan vek bio svega 35,22 godine. Žensko stanovništvo je umiralo u mlađem dobu iz više razloga, a najznačajniji su bili težak život, rizici trudnoće i rađanja, povezani sa velikom smrtnošću u nehigijenskim uslovima. Prema godišnjim statistikama 1903. godine u Srbiji je umrlo 26,3\% dece u prvoj godini života, a od tog broja je čak $15,2 \%$ bilo one dece koja su živorođena. ${ }^{3}$ Ovakva situacija motivisala je uglednog ginekologa dr Jovana Jovanovića, ${ }^{4}$ šefa ginekološkog odeljenja Državne bolnice, koji je bio svestan značaja preventivne zaštite žena i odojčadi, da pokrene nekoliko značajnih akcija. Učestvovao je u osnivanju Škole za babice u Beogradu i uređenju babičke službe u Srbiji, radio je na osnivanju dispanzera za majke i dojenčad, poliklinike za porodilje, sreskog

\footnotetext{
${ }^{1}$ Arhiv Srbije (AS), Ministarstvo prosvete Srbije (MPs), XXI, 147, 1883. Žensko društvo je za svako dete (9 dečaka i 7 devojčica) primalo mesečnu novčanu nadoknadu. Tim novcem im je plaćan smeštaj, a dečaci i devojčice su bili smešteni u posebnim privatnim kućama.

${ }^{2}$ Školski list, god. XIII, br. 9, Sombor, 15. 5. 1881, 139.

${ }^{3}$ Dubravka Stojanović, „U senci 'velikih narativa': Stanje zdravlja žena i dece u Srbiji početkom XX veka“, u: Žene i deca, 4. Srbija u modernizacijskim procesima XIX i XX veka (Beograd: Helsinški odbor, 2006), 162-165.

${ }^{4}$ Dr Jovan Jovanović (1870-1923), rođen u Beogradu, gimnaziju završio u Novom Sadu a medicinu u Beču gde je specijalizirao ginekologiju. Za šefa ginekološkog odeljenja Državne bolnice u Beogradu postavljen je 1896, za upravnika Babičke škole 1901, a bio je i sekretar u Glavnom sanitetskom savetu. Zbog političkih razloga penzionisan je 1910, a za šefa ginekološkog odeljenja Državne bolnice ponovo je postavljen 1919. Bio je član Srpskog lekarskog društva i objavio je nekoliko udžbenika i više članaka na srpskom i nemačkom jeziku.
} 
porodilišta u Grockoj, a često je pisao o zdravstvenoj i socijalnoj zaštiti dece. ${ }^{5}$ Tražeći način da se pomogne napuštenoj i bolesnoj deci i samohranim majkama, krajem 1904. učestvovao je u stvaranju Materinskog udruženja, a 1911. i društva Srpska majka.

\section{Materinsko udruženje 1904-1914.}

Dr Jovan Jovanović je kao upravnik Babičke škole bio često suočen sa slučajevima kada su majke posle porođaja u porodilištu te škole napuštale decu. Za nahočad - napuštenu decu bila je, po zakonu, nadležna opština na čijoj je teritoriji dete ostavljeno i pronađeno. U nemogućnosti da se tek rođena deca smeste u postojeći Dom za sirotnu decu, opštinski organi su odojčad i manju decu smeštali kod privatnih lica kojima su za to hraniteljstvo plaćali. Najmlađa napuštena deca su često umirala zbog nehigijenskih uslova i različitih bolesti, a ni uslovi u hraniteljskim, najčešće vrlo siromašnim, porodicama nisu bili zadovoljavajući. Zbog toga se dr Jovanović pismom u novembru 1904. obratio Sari Karamarković i zamolio je da pokuša da osnuje jedno humano udruženje koje bi radilo na smanjivanju smrtnosti kod dece i na zaštiti nezbrinute siročadi. Ona se posle savetovanja sa dr Dragom Ljočić prihvatila tog posla i 4. decembra okupila grupu prijateljica kojima je dr Jovanović izložio svoje ideje. ${ }^{6}$ Cilj ovog društva bi bio da se osnuje higijenski dom za odojčad i decu do 7 godina i da se u njemu odgajaju deca lišena roditeljske nege. ${ }^{7}$

Prva pravila Materinskog udruženja, koja su pripremili dr Jovan Jovanović i dr Draga Ljočić, sastavljena su već 6. decembra, a odobrena 10. decembra 1904. godine. Na osnivačkoj skupštini održanoj na Materice 12. decembra 1904. u sali Crvenog krsta govorila je Sara Karamarković, a dr Jovan Jovanović je opširnije izneo pravce rada društva. Tom prilikom za predsednicu je izabrana Sara Karamaković, za potpredsednicu dr Draga Ljočić, za blagajnicu Smilja Ristić, a za delovođu Olga Isaković. Osnivačkom sastanku prisustvovale su i: Jelena Riznić, Jela Stokić, Mileva Barlovac, Mileva Dževairović, Mila Jovanović, supruga dr Jovanovića, Naca Stefanović, Sofija Lj. Ivanović, Smilja B. Ristić i Hristina Jovanović.

Na samom početku rada Materinskog udruženja najveći doprinos su dale predsednica društva Sara Karamarković i potpredsednica dr Draga Ljočić. Sara D. Karamarković (1836-1910) postala je članica Ženskog društva odmah

\footnotetext{
5 Jovan J. Jovanović, „Materinsko udruženje“, Narodno zdravlje, br. 1, (1905), 5: „A baš u našoj maloj državi je svaki čovek potreban. Mi bez nužde gubimo godišnje nekoliko hiljade dece, koja se mogu bez velike muke spasti i biti zdravi i dobri građani. Šta nam vredi naša čuvena plodnost, kad je dokazano da jedva 40 od 100 bračne dece doživi 14-tu godinu; kod nas ima krajeva, gde više umre, nego što ih se rodi; kad ima prilika da se iz naroda ne može rekrutovati samo za to, što je čitava jedna godina, čitavo jedno koleno još u ranom detinjstvu izumrlo. Mi moramo ljudski materijal da kapitališemo ako hoćemo dalje da opstanemo.“

${ }^{6}$ Spomenica proslave dvadesetpetogodišnjice Materinskog udruženja (Beograd: b. i., 1930), 20.

${ }^{7}$ Dom Materinskog udruženja u Beogradu, posvećeno svečanom otvaranju Doma Mat. udruženja 4. decembra 1925. god, za štampu priredila Dar. Ć. Panić (Beograd: b. i., 1926), 7-8.
} 
po njegovom osnivanju 1875. Obavljala je mnoge važne i zahtevne poslove u Ženskom društvu - bila je administratorka Domaćice, nadzornica Pazara, potpredsednica društva je postala 1889, a predsednica 1890. U avgustu 1900. podnela je ostavku, verovatno nezadovoljna odnosom uprave i dela članstva prema prvoj pokroviteljici kraljici Nataliji i zbog izbora kraljice Drage Obrenović za novu pokroviteljicu. Među osnivačicama Materinskog udruženja bila je i jedna od najaktivnijih humanih radnica i velika dobrotvorka Hristina K. Jovanović, osnivačica Ženskog društva i potpredsednica od aprila 1878. do kraja 1882. godine. Sofija Ivanović, supruga pukovnika i ministra Ljubomira Ivanovića, takođe je bila članica prve uprave, potpredsednica 1884, predsednica 18851886; nadzornica beogradske vojne bolnice 1885; predsednica Literarnog odbora 1896-1899. Podršku u osnivanju dala im je i Naca Stefanović, nekadašnja potpredsednica Ženskog društva koja je takođe podnela ostavku 1900. Zahvaljujući profesionalnim i humanim akcijama dr Drage Ljočić društvo je brzo počelo da radi ne samo na zdravstvenoj zaštiti napuštene dece, već i na podizanju opšte socijalne svesti srpskog, pre svega beogradskog građanstva. Suočena od samih početaka sa velikim poteškoćama u svom profesionalnom razvitku, ona nije propuštala priliku da propagira i širi ideje rodne ravnopravnosti i hitne potrebe da se zaštite i samohrane majke. ${ }^{8}$

Zahvaljujući uglednoj upravi Materinsko udruženje je vrlo brzo prikupilo članstvo i započelo dugotrajan posao u ostvarivanju ciljeva društva koji su definisani u prvom članu Pravila: „Cilj je društvu da primi pod svoje staranje sirotnu i napuštenu novorođenu decu bar do $7 \mathrm{im}$ godine, prvenstveno onu, koja se rode $\mathrm{u}$ porodilištu Babičke škole i onu, za koju opštine ili pojedinci budu društvu naknadili troškove oko izdržavanja. Sem toga je društvu cilj da po mogućstvu potpomaže sirotne žene posle porođaja dok se za rad ne osposobe, prvenstveno one, koje su se porodile u porodilištu Babičke škole. " 9 Ostali članovi koji su se odnosili na unutrašnju organizaciju, upravu, članove, bili su vrlo slični drugim pravilima koja su do tada osnovana ženska društva imala. Njihova glavna briga je bila da se što pre osnuje preko potreban Dom za nahočad. U finansijskom pogledu oslanjale su se na redovne članarine, dobrotvorne priloge i priloge Beogradske opštine koja ih je podržala od samog osnivanja. Društvom je rukovodila Uprava koju su činile 33 članice izabrane na redovnoj skupštini na tri godine. Iz njihovih redova su se birali predsednica, potpredsednica, delovođa i blagajnica društva. Član 9 govori o dužnostima uprave u budućem domu, pa se navodi da će sve upravne članice svakodnevno dežurati i ,voditi nadzor nad negom i vaspitanjem primljene dece“, primati ili otpuštati personal Doma. Kako su znale da će izdržavanje budućeg doma iziskivati velike finansijske izdatke, odmah su predvidele i stvaranje Nad-

\footnotetext{
${ }^{8}$ Više o dr Dragi Ljočić u: Jasmina Milanović, „Prva ženska bolnica u Kneževini Srbiji 1876-1877“, u: 800 godina srpske medicine, Treći Sokolski zbornik, urednik Zoran Vacić (Beograd: Srpsko lekarsko društvo, 2017), 15-34; Snežana Veljković, Izgubljena bitka dr Drage Ljočić, http://www.rastko.rs/ rastko/delo/15022 (pristupljeno 13. 3. 2015); Srpkinja, njezin život i rad, njezin kulturni razvitak $i$ njezina narodna umjetnost do danas (Irig: Dobrotvorne zadruge Srpkinja u Irigu, 1913), 43; Dragan Ivanović, Kolevka zdravstva u Srbiji, knj. 1 (Ruma: Srpska knjiga, 2003), 109-114.

${ }_{9}^{9}$ Pravila društva Materinskog udruženja (Beograd: Društvo Materinskog udruženja, 1904), 3.
} 
zornog odbora koji će biti sastavljen od predsednika Beogradske opštine ili njegovog zamenika, upravnika Babičke škole i jednog dobrotvora društva. O radu društva tokom prve tri godine postojanja ostali su vrlo iscrpni izveštaji koji su, zahvaljujući velikim zaslugama Sare Karamarković i živim vezama koje je zadržala u Ženskom društvu, objavljivani u časopisu Ženskog društva Domaćica. Ovi izveštaji su danas dragocena građa za istoriju samih početaka ovog društva, njegovih akcija, ali i međusobnih odnosa osnivača i članova. ${ }^{10}$

Zahvaljujući plemenitim ciljevima novog društva u prvoj godini rada prikupile su 115 članica, naredne 1906. godine ih je bilo 159, a 1907. broj redovnih članica društva je bio 194. Iako su raspolagale skromnim sredstvima već posle godinu dana, 15. januara 1906, otvoren je prvi dom Materinskog udruženja - Dom za nahočad u Studeničkoj ulici br. 34. Prva deca su u Dom primljena još 1 . decembra 1905. i to osmoro opštinske dece u uzrastu od mesec dana do dve godine. Na početku je primljeno i nekoliko beba sa majkama koje su u Dom došle kao dojilje. Dr Draga Ljočić je volonterski radila kao upravnica Doma, dok su pomoćni lekari bile dr Marija Vučetić, dr Ljubica Gođevac, dr Marija Zibold i dr Marija Savić. Već na početku rada doma, međutim, pojavila su se različita mišljenja među osnivačima društva. Početkom 1906. godine dr Jovanović, upravnik Babičke škole, uložio je protest jer se u Dom nisu primala deca iz Babičke škole. Odgovorila mu je potpredsednica dr Draga Ljočić, napomenuvši da to ne može da se sprovede jer nisu ispunjeni uslovi koji su obećani od strane upravnika Babičke škole: snabdevanje hranom, rubljem, odgovarajućim stanom i privatnim prilogom. ${ }^{11}$ Dragocenu pomoć udruženje je primalo od države, preko Sanitetskog odeljenja Ministarstva unutrašnjih poslova. Ministarstvo je za svog komesara koji će kontrolisati kako se taj novac troši postavilo upravo dr Jovana Jovanovića. Na tu vest uprava se pobunila i predsednica i potpredsednica su otišle u posetu ministru unutrašnjih dela i uspele su da izdejstvuju da odluka o postavljanju državnog komesara bude poništena. Postavljanje državnog komesara bi značilo da društvo gubi autonomiju u vođenju Doma. Kontrolu nad utroškom državnih sredstva od tada je vodio načelnik Sanitetskog odeljenja, koji je ujedno bio i član Nadzornog odbora Materinskog udruženja.

Kako su opštine bile nadležne da se brinu o napuštenoj deci, Materinsko udruženje je od samog početka svog rada bilo u stalnom kontaktu sa predsednikom Beogradske opštine, a dobijalo je i znatna sredstva od opštine. Za uzvrat su prihvatale decu o kojoj se opština brinula i koja su u početku smeštana kod pri-

10 „Izveštaj Materinskog udruženja za 1906. godinu“, Domaćica, organ Ženskog društva i njegovih podružina, god. XXX, br. 5, (Beograd, maj 1907), 1-18; „Godišnji izveštaj uprave Materinskog udruženja za 1907. god.“, Domaćica, god XXIX, br. 5, (Beograd, maj 1908), 1-21; „Materinsko udruženje u 1908. godini, godišnji skup držan 30. januara 1909. god.“, Domaćica, god. XXX, br. 2, (Beograd, februar 1909), 5-12. Godišta Domaćice za 1906. i 1907. pogrešno su ubeležena. Još 1894. preskočena je jedna godina, pa je to tek 1908. uočeno i ispravljeno. Zbog toga je 1907. godina označena kao XXX godina izlaženja časopisa, a 1908. kao XXIX, što je opet bilo pogrešno jer je to bila XXX godina izlaženja časopisa Domaćica koji je osnovan 1879. godine. To pogrešno obeležavanje godine izlaženja nije ispravljeno ni u međuratnom periodu.

11 „Izveštaj Materinskog udruženja za 1906. godinu“, Domaćica, br. 5, (1907), 1. 
vatnih lica. Tako su sredinom aprila 1906. preuzele brigu o dvadesetoro dece o kojima se starala opština. Ova deca su prvo pregledana od strane lekara, kako ne bi donela neku zaraznu bolest ili ušljivost u Dom, a potom im je nabavljena nova odeća i obuća. Navodi se da su ta deca bila jako zaostala u fizičkom razvoju, vaspitanju i održavanju čistoće i da je za njih bio pravi spas što su došla u Dom. U periodu od 1. decembra 1905. do 1. januara 1907. u Dom je primljeno i negovano ukupno 71 dete, 36 dečaka i 35 devojčica. Od ukupno primljena 24 opštinska deteta, samo je 3 udomljeno, a petoro je preminulo. Opština je za decu plaćala po 20 dinara mesečno. Od „društvene“ dece kojih je primljeno 20 u ovom periodu, iz doma je otišlo 12, a preminulo 3. Društvena deca su uglavnom bila deca samohranih majki koje su se nalazile u teškom materijalnom ili zdravstvenom stanju. Bilo je i dece čije su majke umrle na porođaju, a očevi su već brinuli o više nejake dece. Od ,privatne“ dece, koja su u Dom smeštana uglavnom zbog bolesti i nemogućnosti porodice da se o njima stara, iz Doma je izašlo 14, dok je 7 umrlo. Boravak ove dece u Domu plaćali su roditelji ili rodbina deteta. Po rečima dr Ljočić postotak smrtnosti dece u Domu bio je manji nego u sličnim domovima u inostranstvu, gde je iznosio $25-30 \%$, dok je u ovom Domu bio $21 \%$.

Angažovanje uglednih beogradskih gospođa i predan rad beogradskih lekarki koje su imale već izgrađenu profesionalnu reputaciju i brojna državna odlikovanja nisu promenili odnos većeg dela javnosti prema radu ovog društva. U javnosti je ovo udruženje glasno kritikovano, sa obrazloženjem da se tako širi nemoral, pošto su većina štićenica i štićenika bila vanbračna deca. Tako se borba za zaštitu napuštene dece pretvorila u borbu protiv predrasuda. ${ }^{12} \mathrm{U}$ tome im je naročito pomogla poseta kralja Petra I Karađorđevića sredinom novembra 1906, neposredno pred slavu društva (Vavedenje presvete Bogorodice), koji je tom prilikom poklonio 100 dinara u zlatu. Uskoro je princeza Jelena Karađorđević prihvatila da bude pokroviteljica Materinskog udruženja i njihovog Doma. Poseta kralja i pokroviteljstvo, kao i posebna pažnja celog kraljevskog doma koja je ukazivana Materinskom udruženju predstavljali su prekretnica u radu društva.

Kako zdanje u kome je Dom za nahočad započeo rad nije bilo uslovno, uskoro su deca preseljena u novi Dom u Resavskoj ulici br. 90. Tu zgradu je mitropolit Dimitrije dao na upotrebu Materinskom udruženju, uz plaćanje kirije. Dom je mogao da primi dvadesetak dece, ali je već 1907. godine imao 42 pitomca o kojima je društvo vodilo brigu. ${ }^{13}$ Vrlo brzo se pokazalo da ni ova zgra-

${ }^{12}$ Spomenica proslave dvadesetpetogodišnjice Materinskog udruženja, 25-26: „Ali Materinsko Udruženje od početka svoga rada nije imalo samo obeležje jednog čisto humanog društva, koje u svome radu nailazi na pomoć i odobravanje. Ono je primilo na sebe jedan veliki socijalni zadatak: da se bori protiv predrasuda, koje su udarale žig prezrenja i sramote potpuno nevinim bićima, koja tek što su došla na svet, i koje su osuđivale na propast nesretnu majku.... S toga je Materinsko udruženje i svoju drugu zadaću, vaspitavanje i propagiranje dečije zaštite, takođe dostojno izvršilo, tako da se može smatrati kao preteča ne samo svima društvima za zaštitu nezbrinute male dece, nego i kao preteča celokupnom organizovanom radu na zaštiti dece u našoj zemlji, koji je država, po Ujedinjenju našega naroda, potpuno prihvatila.“

13 Almanah humanih društava, ur. Siniša Sretenović i Božidar Nedeljković-Ročkoman (Beograd: izdanje urednika, 1940), 96. 
da nije dovoljna za smeštaj dece, niti je ispunjavala sve zdravstvene i higijenske uslove. Kuća se nalazila u blizini bolnice, što je bilo važno, a imala je i veliku baštu pa su deca mogla da provode leti veći deo dana na vazduhu. Zbog toga su članice društva nastavile da prikupljaju novac i za gradnju nove namenski zidane zgrade doma organizujući koncerte, igranke, lutrije, animirajući javnost u prikupljanju sredstava. U tome su im pomogle i supruge stranih diplomatskih predstavnika, koje su se ovom prilikom prvi put angažovale u javnom životu Srbije. Supruge ruskog i engleskog poslanika, Sergejeva i Vajtheda, priredile su zabave 1. i 2. novembra 1907. u Građanskoj kasini. Gospođa Vajthed je 1. novembra priredila prodajnu izložbu reprodukcija umetničkih slika. U drugom delu Kasine gospođa Sergejev je organizovala bogat bife gde su se prodavali čaj i razne đakonije. Tom prilikom mitropolit je održao govor o humanizmu, dr Draga Ljočić je govorila o Materinskom udruženju, a Bogdan Popović o umetnosti. ${ }^{14}$

Članice udruženja su nastojale da se upoznaju sa savremenim dostignućima u negovanju odojčadi. Preko austrijskog konzula obaveštene su da je u Beču 1906. osnovano društvo „Dete“ sa kojim su stupile u kontakt. Početkom 1907. godine dve izaslanice društva - Jelena Riznić i Johana Levi, posetile su njihovu izložbu i članicama bečkog društva predale pismo koje je u ime uprave napisala dr Marija Zibold. U jesen 1907. potpredsednica dr Draga Ljočić sa članicom uprave Nacom Stefanović posetila je u Temišvaru azil za malu decu i tom prilikom pokušala da nađe dadilje za svoj Dom.

Tokom 1907. članice su u najčešćoj prepisci bile sa Beogradskom opštinom o pitanju dobijanja zemljišta za izgradnju doma, ali i zbog drugih problema koji su se pojavljivali. Sredinom jula potpredsednica dr Draga Ljočić je podnela izveštaj o stanju Doma u koji je bilo potrebno uložiti veća novčana i materijalna sredstva, obezbediti stručan personal i naći bolji smeštaj kako bi se odojčad odvojila od veće dece. Takođe je upućeno pismo Opštini beogradskoj da više ne šalje u Dom nahočadi bolesnu decu, jer se više puta dešavalo da su poslata veoma bolesna deca koja su ubrzo po dolasku umrla. Od tog vremena u Dom će se primati samo zdrava deca koju je prethodno pregledao opštinski lekar, a bolesnu će upućivati prvo u bolnicu, pa potom kada ozdrave u Dom. Uprava je za prvo vreme predložila da se za veću decu nađe drugi smeštaj, a da samo odojčad ostanu u ovoj zgradi Doma, što je uskoro rešeno iznajmljivanjem još jedne kuće. ${ }^{15}$ Tokom 1907. negovano je ukupno 72 dece, a od tog broja novoprimljenih je bilo opštinske 16 , društvene 18 i privatne dece 11 . Od tog broja umrlo je 25 dece koja su bila u prvim mesecima života, dok u grupi dece od godinu dana pa naviše nije umrlo nijedno. Važno je da tokom čitave godine nije bilo slučajeva infektivnih bolesti u Domu, što govori o tome da je, i pored neuslovnog smeštaja, zahvaljujući stalnom zdravstvenom nadzoru dežurnih lekarki i ostalog personala, dobrom ishranom i pažnjom, mortalitet značajno smanjen. U oktobru 1907. Opština je najzad ponudila plac Materinskom udruženju

\footnotetext{
14 „Dom za odojčad“, Pravda, br. 305, 3. 11. 1907, 1. U članku je naziv društva pogrešno naveden, pa umesto Materinskog udruženja stoji: društvo „Srpskih Matera“.

15 „Godišnji izveštaj uprave Materinskog udruženja za 1907. god.“, Domaćica, br. 5, (1908), 1-21.
} 
za izgradnju Doma, ali zbog različitih administrativnih i drugih poteškoća, ovo pitanje neće biti rešeno. U martu 1911. Društvo za pomaganje sirote i napuštene dece ustupilo je zemljište na uglu Vojvode Milenka i kralja Milutina Materinskom udruženju, što je predsednik opštine Ljuba Davidović potvrdio 19. aprila 1912. Međutim, zbog početka balkanskih, a potom i Prvog svetskog rata, na tom zemljištu nije tada započeta izgradnja Doma. ${ }^{16}$

Početkom 1908. godine Sara Karamarković je podnela ostavku i izabrana je za počasnu predsednicu. Nova predsednica društva je postala dr Draga Ljočić, potpredsednica Olga Isaković, a za delovođu je izabrana Katarina Holec, dugogodišnja upravna članica i delovođa Ženskog društva. Još u toku 1907. godine usvojen je predlog da se stvori uže telo koje će se češće sastajati i rešavati važna pitanja za rad Doma. Početkom 1908. taj odbor je sastavljen i u njega su ušle: upraviteljka doma, blagajnica i delovođa društva i nekoliko upravnih članica. Kako bi prikupile što više sredstava i zainteresovale javnost za položaj ove dece, dr Draga Ljočić je predložila da upravne članice uzmu po jedno dete na staranje. Još ranije je Sara Karamarković preuzela brigu o jednoj devojčici, a isto su uradile Mara Klidis i Mileva Barlovac.

Dr Draga Ljočić je na glavnom skupu 1909. godine opet govorila o uslovima u Domu i mortalitetu dece, koji je bio predmet i pojedinih javnih optužbi na račun društva i uslova u Domu. ${ }^{17}$ Tom prilikom je rekla: „Mi, napriliku, ne možemo i ne smemo da ograničimo striktno broj primanja dece, to ne smemo iz obaveze prema opštini i moralne obaveze spram nevoljne dece, koja se nalaze bez skloništa. Iz navedenih razloga vidite da su prekori, koji nam se čine odnosno umiranja dece neopravdani. Poznato je, da je mortalitet kod dece u prvim mesecima i godinama $u$ opšte vrlo veliki i da sa tim treba uvek računati. “18 Dalje navodi kako su posebno u kritičnom stanju deca koja se kao nedonoščad donose u Dom sa malom telesnom težinom i da retko koje od njih preživi te prve dane. Tokom 1908. godine u Domu su negovana 83 deteta, i to 41 muško i 42 ženska. Opštinske dece je bilo 40, društvene 24 i privatne 19. Ukupno su preminula 23 deteta, među kojima je bilo najviše opštinske dece rođene sa malom težinom. Od ovog broja bilo je petoro prevremeno rođene dece koja nisu mogla da prežive. Kao veliki uspeh dr Draga Ljočić je istakla da u protekle tri

\footnotetext{
${ }^{16}$ Spomenica proslave dvadesetpetogodišnjice Materinskog udruženja, 92-94.

17 „Iz Beogr. Materin. Udruženja“, Pravda, br. 112, 24. 4. 1908, 2-3. Uredništvo Pravde je prema dopisu iz Šapca koji je potpisan samo sa „X“ napisalo oštar i osuđujući članak protiv Materinskog udruženja. U njemu je direktno optužilo za smrt muške bebe koju je otac Ljubiša Marković, trgovac iz Šapca, posle smrti žene doneo u Dom. Posle 15 dana je pozvan iz udruženja da dođe po dete. Po rečima šabačkog lekara koji je dete potom pregledao našao je da je dete izgubilo mnogo na težini, ali da nije bolesno. U daljem tekstu stoji: „Mi tražimo od nadležnih, da po dužnosti svojoj bez obzira, na auktoritet pojedinaca - povede najenergičniju istragu po ovoj stvari - a mi im, sa originalnim lekarskim uverenjem, stojimo na raspoloženju. - A vama roditeljima, koji imate decu u tome zavodu, savetujemo, da ih još za vremena izvadite iz inkvizitorskog doma, ako ne želite da iskusite iste posledice, koje je iskusio nesrećni roditelj deteta o kome je ovde reč.“

18 „Materinsko udruženje u 1908. godini, godišnji skup držan 30. januara 1909. god.“, Domaćica, br. 2, (1909), 11.
} 
godine u Domu nije bilo nijedne zaraze, ni šarlaha ni difterije koje su tada za decu bile smrtonosne bolesti. Dr Draga Ljočić je 1910. godine podnela ostavku i izabrana je za počasnu predsednicu. Od te godine predsednica udruženja je postala Olga Isaković, a potpredsednica Naca Stefanović. Olga Isaković je zbog premeštaja iz Beograda dala ostavku, a za predsednicu je u januaru 1913. izabrana dugogodišnja blagajnica Leposava Biba.

U narednom periodu, do 1914. godine, situacija u Domu se nije mnogo promenila. Pored pomoći opštine, društvo je dobijalo i stalnu godišnju pomoć od Sanitetskog odeljenja Ministarstva unutrašnjih dela. Rad društva je pomagalo i Srpsko društvo Crvenog krsta, kao i brojni pojedinci, naročito beogradski trgovci. Nažalost, rad društva je bio ograničen samo na Beograd, pa se u unutrašnjosti malo ko brinuo za nezbrinutu i napuštenu decu. Pred početak Prvog svetskog rata uočen je veći broj ostavljene dece, posebno u Beogradu. Međutim, i dalje je reč o relativno malom broju u odnosu na broj dece koja su ostavljana $u$ većim gradovima srednje Evrope, a nemerljivo manji u odnosu na gradove zapadne Evrope. Naravno o čedomorstvu i broju ubijenih živorođenih beba nema pouzdanih podataka, pa se o toj pojavi i ne može govoriti u brojkama. ${ }^{19}$

Materinsko udruženje je učestvovalo u stvaranju Srpskog narodnog ženskog saveza 5. oktobra 1906. godine, zajedno sa Beogradskim ženskim društvom, Odborom gospođa Kneginja Ljubica i Kolom srpskih sestara. Još sredinom aprila 1906. predsednica Ženskog društva je poslala pisma svim ženskim udruženjima u Srbiji sa ponudom da stvore savez i da pošalju kratke izveštaje o svom radu kako bi se štampali u Domaćici, što je uprava Materinskog udruženja sa zadovoljstvom prihvatila. Početkom septembra stigao je novi predlog da Materinsko udruženje izabere četiri predstavnice koje će sa predstavnicama ostalih ženskih društava obrazovati poseban odbor kako bi dočekale dve gošće koje će u oktobru doći u Beograd. Reč je bila o dočeku Keti Širmaher, feministkinje koja je posetila Beograd na poziv Savke Subotić kako bi održala predavanje o feminizmu i razgovarala o daljoj organizaciji saveza. Izabrane su Agnica Srećković, Mica Pavlović, dr Marija Zibold i dr Ljubica Gođevac. Tokom maja 1907. raspravljalo se na sednici uprave Materinskog udruženja o „Pravilima za međunarodni savez ženskinja“ koja su im poslali. Dale su neke primedbe, ali su i predložile da u Savez uđu još i predstavnice Doma učenica i Jevrejskog ženskog društva. Primedbe na „Pravila

19 „Beogradska nahočad“, Pijemont, br. 168, 3. U tekstu se iznosi da je u Beogradu tokom 1912. godine pronađeno 11 ostavljene dece, 1913. - 14, a u prvoj polovini 1914. - 12. Skreće se pažnja na zakonske odredbe koje samo istražuju i krivično gone majku, a za oca se niko ni ne raspituje, a ta deca su van zakona, najčešće deca obeščašćenih devojaka ili prostitutki, „koja rođenjem ispaštaju greh svojih roditelja.“ Dalje autor zaključuje: „Beogradska su nahočad deca van zakona, deca greha i deca sirotinje.“ To je potkrepljeno i statistikom po kojoj su od 12 majki koje su nađene, 3 bile služavke, pralje i sl., 2 su bile udovice, raspuštenice, 3 obeščašćene devojke, 2 prostitutke, pevačice, 1 udata žena i 1 seljanka. Sva deca koja se nađu na beogradskim ulicama se kao „opštinska deca“ upućuju na čuvanje i negu u dom Materinskog udruženja u Resavskoj ulici br. 82. Tu su čuvana do treće godine i onda se otpuštaju iz Doma i predaju opet opštini. U Domu je u junu 1914. bilo 40 dece i od tog broja petoro dece izginulih ratnika, 8 dece zavodskih dojilja i 25 vanbračne dece. 
za savez Srpkinja“ koje je predložilo Materinsko udruženje su bile: „1) Da se ženskom detetu, ženi, osigura položaj i ravnopravnost u porodici. 2) Da se ženskom polu reguliše zakonom položaj u društvu kao ravnopravnom članu društva i u državi kao ravnopravnoj građanki.“ Dalje se navodi: „Prema tom Savez ima da zahteva od Vlade i Narodnog Predstavništva na prvom mestu da se poništi čl. 921 Građanskog zakona koji divljački ponižava i vređa ženski pol direktno, a indirektno ponižava svakog svesnog muškarca koji oseća ljubavi i poštovanja spram majke, ćerke, žene i sestre, koji se tim članom stavljaju u kategoriju raspikuća i umno obolelih." Osim toga, tražile su i izmenu člana 397 koji govori o nasleđu sa zahtevom da sva deca podjednako dele imanje. Zahtevale su i izmenu člana 130 po kome se za vanbračno dete traži i zna samo majka, pa zahtevaju da se istraži i pronađe i otac takvog deteta. Takođe su tražile izmenu čl. 446 po kome ženska osoba ne može biti svedok, „sem osobite nužde“, kao i da se u građanski zakon unese član koji će ženske službenike izjednačiti sa muškim kolegama u pogledu nagrada, unapređenja i penzije. Posebno smatraju da Internacionalni savez žena, a naročito Savez Srpkinja treba da, u sporazumu sa nadležnima, brine i uzme u zaštitu prostitutke „roblje - živ espap“, kako su ih nazvale u svom predlogu. „Sklop današnjeg društva je takav, da bi bila prava utopija boriti se protiv te sramne institucije, ali baš s toga dužnost je žena, da tim bednicama regulišu položaj i odnose s njihovim gazdama; treba Savez da uspe da kao moralna vlast može da utiče i zaštićava ta ponižena odbačena bića ili bolje reći predmete. “" ${ }^{\text {"20 }}$ Svoju borbu za bolji položaj žena nastavile su i u međuratnom periodu kao stalne članice Jugoslovenskog ženskog saveza.

\section{Materinsko udruženje 1914-1941.}

Tokom Prvog svetskog rata Dom je nastavio da radi, čak i u vreme okupacije. Nadzornica Natalija Popović je teškom mukom uspela da održi rad, nahrani i obezbedi decu, koju su u vreme bombardovanja Beograda izmestile na periferiju grada radi sigurnosti. Posle okupacije Dom se našao u teškom položaju, a broj smeštene dece je rastao. Nestašica ogreva i hrane je dodatno otežavala funkcionisanje pa je nekoliko supruga austrijskih oficira priskočilo u pomoć i počelo da pomaže Dom. Lekarke dr Slavka Mihajlović i dr Ljubica Gođevac su redovno obilazile decu i u ovom periodu, a veliku pomoć su im pružali upravnik bolnice dr Dušan Stojimirović i apotekar Stojić. Beogradska opština u vreme okupacije i dalje je pomagala Dom, koliko je mogla, ali sada nije davala novac, već hranu i ogrev koji su im bili preko potrebni. Tokom 1916. godine u Domu je boravilo u proseku između 40 i 60 dece. Pokroviteljica Doma je od decembra 1915. do oktobra 1916. bila gospođa Ana Franc, a u novembru 1916. pokroviteljstvo je primila baronica Ida Lang. One su se takođe starale da se prikupljaju pokloni, odeća i hrana za decu. Čak je i srpski Crveni krst preko Ženeve uspevao da pošalje novčane priloge Domu. ${ }^{21}$

\footnotetext{
20 „Godišnji izveštaj uprave Materinskog udruženja za 1907. god.“, Domaćica, br. 5, (1908), 5-6.

${ }^{21}$ „Grad i okolica. Rad opštine grada Beograda“, Beogradske novine, br. 271, 12. 11. 1916, 2; Beogradske novine, br. 189, 12. 7. 1917, 2.
} 
Posle Prvog svetskog rata Materinsko udruženje je nastavilo rad, a brigu o Domu i deci ponovo je preuzelo 1. juna 1919. godine. Bilo je suočeno sa velikom nestašicom hrane i sve većim brojem dece koja su pristizala u Dom. Ta deca su bila vrlo slaba i zaražena raznim bolestima, često neizlečivim. Brigu o deci vodio je lekar Doma dr Kosta Jovanović koji je činio sve što je bilo u njegovoj moći. Predsednica Leposava Biba je zbog bolesti podnela ostavku u decembru 1920, a na njeno mesto je 19. aprila 1921. izabrana Zorka Vlajić, dugogodišnja članica, koja će Materinsko udruženje voditi narednih dvadeset godina. Dr Draga Ljočić je bila počasna predsednica, potpredsednica Julka Bajloni, delovođa Melanija Pavlović, a blagajnice Natalija Popović i Ruža Pavlićević.

Prvi zadatak je bio da se nastavi akcija oko podizanja nove zgrade Doma. Stvoren je i Odbor za zidanje Doma Materinskog udruženja u kome su bili: Zorka Vlajić, Julka Bajloni, Melanija Pavlović, Natalija Popović, Darinka Panić, Zorka Andonović, Zorka Lazarević, Leposava Biba, Jelena Riznić i Ljubinka Ilić, a kasnije su im se priključile Kosara Veljković i Danica Vasić. Kako bi u skučenim uslovima ipak mogle da ponude što bolji smeštaj, članice su se dogovorile, uz konsultaciju sa lekarima, da primaju samo decu do 3 godine starosti. Društvo za pomaganje sirote i napuštene dece - koje se 1919. godine spojilo sa Društvom za zaštitu dece, stvorenim za vreme rata, u novo Društvo za vaspitanje i zaštitu dece - opet je priskočilo u pomoć. Materinskom udruženju je ponovo ustupljeno zemljište na uglu Vojvode Milenka i kralja Milutina pod istim uslovima pod kojim su ga i oni dobili (korišćenje na 50 godina), sa čim se saglasila i Beogradska opština. Udruženje je imalo prikupljenu svotu od 36.655 dinara, koja je pre rata bila značajna svota novca, ali u novim uslovima je postala zanemarljiva. Najveću pomoć su dobili od Blanš Vesnić, supruge srpskog i jugoslovenskog ambasadora u Parizu Milenka Vesnića. Ona je bila na čelu fonda „Udruženje za spasavanje srpske dece u Parizu“" koje je poslalo 200.000 dinara za podizanje doma. Velike priloge su dala ministarstva, pre svih ministarstvo socijalne politike, mnoge ustanove $\mathrm{i}$ beogradski trgovci. Plan za podizanje doma je uradio arhitekta Dimitrije Leko, uz živo učešće članica društva čije su pojedine upravne članice posetile slične ustanove u Parizu, Pragu, Subotici i Ljubljani. Priloge su u inostranstvu prikupljale i Mabel Grujić u Americi - 77.200 dinara, Ana Hristić u Engleskoj, a donatori su bili i gospodin i gospođa Frontingham (63.750 dinara), Mihailo Pupin i drugi pojedinci. Mnogi trgovci i industrijalci su priložili materijal za gradnju. Priložnici koji su dali 5.000 dinara i više postali su veliki dobrotvori i jedna kolevka u Domu je nosila njihovo ime. Imena priložnika od 10.000 dinara i više urezana su na spomen-ploču, a priložnici i legatori od 100.000 dinara stekli su pravo da jedna soba nosi njihovo ime. Kraljica Marija je jednu od prvih poseta posle udaje učinila baš Domu Materinskog udruženja, za slavu 1922. godine, a prilikom rođenja prestolonaslednika poklonila je društvu 100.000 dinara. Kralj i kraljica su zajedno već dali 125.000 dinara priloga. Kao legat Savke Panić dobijeno je 100.000 dinara, koliko im je ostavila i Stana F. Bogojević.

U prisustvu mnogih zvanica temelji Doma su udareni 18. juna 1922. godine. Zidanje i pokrivanje zgrade je završeno po ugovoru do 1. decembra 
1922. godine. Tokom naredne dve godine su završeni i ostali radovi na instalacijama i unutrašnjem uređenju, ali je sve bilo mnogo skuplje od prvobitnih proračuna. Zbog toga je drugi sprat Doma izdat maja 1924. Ministarstvu narodnog zdravlja za zubnu polikliniku. Prenos tapije na zemljište izvršen je 16. septembra 1924, zahvaljujući predsedniku opštine Mihajlu Marjanoviću i potpredsedniku Mihajlu Bobiću, pa je tako Materinsko udruženje postalo pravi vlasnik Doma. Tada je društvo moglo da uzme kredit od 1.500.000 dinara od Državne hipotekarne banke kako bi dovršilo Dom. Jedan deo novca je dala na zajam bez kamate i potpredsednica društva Mila Simić. ${ }^{22}$ Završetak doma i nabavka nameštaja su okončani jula 1925. godine, a deca su preseljena na Petrovdan. Ukupno su na građenje Doma potrošile 6.100.000 dinara, od kojih je Materinsko udruženje prikupilo 2.567 .525 , državna pomoć je iznosila 2.380 .000 dinara uz zajam od banke od 1.500 .000 dinara

Dom za odojčad, kako je zvanično nazvan, svečano je otvoren i osvećen 4. decembra 1925. godine. U početku je u Domu zbrinuto 75 dece i 12 majki, a kasnije je broj smeštene dece povećan na 90 i 18 majki. Uprava doma je poverena doktoru Matiji Ambrožiću, koji je bio profesor Dečije medicine na Medicinskom fakultetu, a kasnije i šef Univerzitetske dečije klinike i Zavoda za zdravstvenu zaštitu matere i deca. Kao pomoćnik i zamenik upravnika radio je dr Uroš S. Ružičić docent na predmetu Dečija medicina, a kao lekar je radila i dr Nadežda Bajić. Negovateljice su bile sestre-nudilje koje su imale propisanu stručnu spremu. Dom je bio autonomna ustanova Materinsko udruženje, koju je finansijski pomagalo Ministarstvo socijalne politike i narodnog zdravlja i Opština grada Beograda. Oni su imali svoje predstavnike u Izvršnom odboru koji je preko upravnika upravljao Domom. Na čelu ovog odbora je bila predsednica Materinskog udruženja. Kao glavne smernice svog budućeg rada članice društva su istakle: „U Domu Materinskog udruženja naći će utočišta i biće negovana podjednakom ljubavlju sva siročad lišena materinske nege, smrću ili bolešću matere ili nesavesnošću odbačena. Treba zaštititi majku - sirotu radnicu ili činovnicu i pomoći joj da očuva svoje dete. Treba raditi na smanjivanju smrtnosti kod dece. Kod nas u našem narodu procenat rađanja je veliki, ali na žalost i smrtnost je dečija velika. Najveći uzrok te velike smrtnosti je neznanje najosnovnijih zakona higijene. Prosvetiti ženu naučiti je tim najpotrebnijim znanjima to je jedan od glavnih zadataka ne samo Materinskog udruženja no sviju, kojima leži na srcu podizanje podmlatka،“'23

Zbog malog broja mesta, a da bi ispunile svoj cilj, članice Materinskog udruženja su u Pravilima Doma navele koja će deca moći da budu primana u Dom: „1. Nahočad; 2. Novorođenčad i odojčad u prvim mesecima, kojima je umrla majka, a nemaju nikoga da ih neguje i hrani; 3. Novorođenčad iz tuberkulozne sredine, koja se samo primanjem u Dom mogu očuvati od infekcije; 4. Odojčad, kojima se majka razbolela, a nemaju nikoga, da ih neguje i hrani, dok majka ozdravi; 5. Veštački hranjena odojčad, kod kojih se poremećaj ishrane i

${ }^{22}$ Godišnji izveštaj Materinskog udruženja za 1925. god. (Beograd: b. i. 1925).

${ }^{23}$ Dom Materinskog udruženja u Beogradu, 27-28. 
varenja ne mogu savladati ambulantno; 6. Novorođenčad u prvim mesecima, koja zbog slabosti trebaju naročitu negu i stalni lekarski nadzor (nedonoščad); 7. Zlostavljena, zapuštena ili ma iz kojih razloga zdravstveno i u opstanku ugrožena veštački hranjena odojčad. “24 U Pravilima društva je navedeno i pod kojim uslovima se u Dom primaju deca sa majkama. Članice društva su uvek zastupale prirodnu ishranu dece, pa su nastojale da primaju što veći broj majki kako bi one što duže dojile decu. Postojao je još jedan razlog zbog kojeg su se članice društva trudile da što više majki sa decom smeste u Dom. Kada je u pitanju bila neželjena trudnoća, period koji bi majka provela uz dete, dojeći ga, stvarao je vezu između nje i neželjenog deteta i često doprinosio da dete ne završi u sirotištu. Ove majke su često u Domu boravile do šest meseci, zaštićene, a ispraćane opremljene za budući život. Majke su u Domu i radile, učile, a imale su priliku i da nešto zarade kao dojilje ili sebi obezbede posao po izlasku iz ovog privremenog skloništa. ${ }^{25}$

Deca koja su smeštana u Dom birana su po utvrđenoj proceduri i prednost su imala ona čiji je život bio ugroženiji, ali i ona koja su imala veće šanse da ozdrave i prežive. Dve trećine mesta u Domu su bila besplatna, a jedna trećina mesta je plaćana iz različitih izvora, od donatora, roditelja, staratelja. U Dom Materinskog udruženja kao svoje štićenike decu su smeštala i državna nadleštva, banovine, opštine iz unutrašnjosti i privatna udruženja koja su se bavila zaštitom dece. Deca su, bez obzira na to da li je njihov boravak u Domu bio plaćen ili ne, imala iste uslove smeštaja i nege. Od 1919. do useljenja u novi Dom 1925. godišnje je primano od 104 do 140 dece. Od 1925. kapacitet je povećan pa su godišnje zbrinjavali preko 250 dece.

Posle otvaranja novog Doma počeo je veliki posao oko preseljenja dece $u$ nov prostor i potraga za stručnim personalom. Jedan deo stručnog personala je došao do kraja 1926. godine, a preostali su stigli naredne godine. Glavni uspeh rada u novim uslovima je bio u znatno smanjenom mortalitetu dece: $u$ 1925. on je iznosio 30\%, 1926. - 23\%, 1927. - 15\%, 1928. - 7\%, 1929. - 6\%. Osoblje se i dalje suočavalo sa lošim stanjem odojčadi koja su donošena u dom, jer su mnoga imala telesnu težinu ispod 2 kilograma. Takođe je bio primetan sve veći broj dece koja su u Dom bila smeštana radi specijalne nege, a naročito ishrane, jer ih druge ustanove nisu primale na lečenje. U Domu je tokom 1927. bilo 191 dete, 1928. 242, 1929. - 228, ukupno 529. Iz Beograda je u ovom periodu bilo 356 dece, a iz unutrašnjosti 207. U istom periodu bračne dece je bilo 168, vanbračne 289 i 1 nepoznatog porekla. Od ove dece tokom tri godine usvojeno je 48 dece. Na usva-

\footnotetext{
${ }^{24}$ Pravila Materinskog udruženja (Beograd: b. i., 1929), 3-11.

${ }^{25}$ Spomenica proslave dvadesetpetogodišnjice Materinskog udruženja, 13-14. O ulozi Doma pisao je i Matija Ambrožić, upravnik: „Dom prima pod svoj krov prvenstveno odojčad, u drugom redu decu do 3 godine. Na prvom mestu se primaju nahočad, dalje novorođenčad, koja su odmah posle rođenja izgubila majku, i dalje bolesnih matera. Dom služi najnežnijem dečjem dobu, gde je razvitak i život u najvećoj opasnosti. Gde zdravstveno stanje dozvoljava materi, da sama neguje svoje dete, ona ga ne može smestiti u Dom. Kada mati sa detetom na sisi nema ni krova ni izdržavanja, primi se dete zajedno sa majkom. Dom nikada ne pomaže odvajanje deteta od matere, nego protežira, gde može, prirodnu vezu deteta sa majkom."
} 
janju dece Dom je sarađivao sa socijalnom sekcijom Materinskog udruženja. Potrebe za smeštaj dece bile su takve da je samo tokom dve godine (1928-1929) uprava Doma morala da odbije preko 500 molbi za prijem dece.

Tokom 1927. godine došlo je do velike promene u organizacionom i finansijskom stanju Doma. Teška finansijska situacija naterala je upravu, a po savetu iz ministarstva, da se oformi Izvršni odbor za rukovođenje Domom Materinskog udruženja u koji bi ušla i lica iz ministarstava i opštine. U Odbor su ušli: od strane Materinskog udruženja predsednica Zorka Vlajić koja je ujedno i predsednica ovog odbora, Julka Bajloni i Zorka Andonović; od strane Ministarstva narodnog zdravlja načelnici: dr Andrija Štampar i dr Ivan Kun, koji je i sekretar Odbora; od strane Opštine beogradske Blagoje Nedić, odbornik i kao savetodavni član bez prava glasa pri rešavanju upravnik Doma dr Matija Ambrožić. Sastavljen je pravilnik za rad Odbora i pravilnik za rad u Domu. Član 1 ovih pravila glasi: „U interesu materijalnog obezbeđenja i stručnog napretka Doma osniva se Izvršni odbor za upravljanje Domom Materinskog udruženja“, a član 20 predviđa da svaka strana zadržava pravo da saradnju prekinu po jednostranom otkazu. U slučaju otkaza sve što je pripadalo Materinskom udruženju automatski se vraća istom na potpuno raspolaganje. $\mathrm{Na}$ ovaj način su članice Materinskog udruženja učinile korak koji im je najteže padao odrekle su se autonomije i nezavisnosti u vođenju Doma, što su do tada uporno branile. Međutim, svesne da funkcionisanje Doma koji je postao velika i zahtevna institucija, naročito u finansijskom smislu, ne može da se zasniva samo na donacijama i nepouzdanim državnim subvencijama, žrtvovale su svoju autonomiju kako bi zaštitile svoju zaostavštinu. Od tog trenutka Ministarstvo narodnog zdravlja je preuzelo plaćanje celokupnog personala, a kasa Doma je odvojena od kase Materinskog udruženja. Ministarstvo je takođe davalo sanitetski i drugi materijal za Dom, dok je Beogradska opština povećala pomoć na 100.000 dinara, davala drva i plaćala lekove. Tokom 1928. po odluci Ministarskog saveta na račun reparacija Ministarstva narodnog zdravlja Dom Materinskog udruženja je dobio kompletnu mlečnu kuhinju, parnu perionicu, aparate za veštačko sunčanje i druge medicinske potrebe. Time je opremanje Doma najmodernijim aparatima i medicinskim pomagalima bilo završeno.

U Dom za odojčad su dolazili na praktičan rad mladi lekari, studenti su dolazili na praksu, kao i učenice Nudiljske škole. Sestre iz dispanzera društva Srpska majka dolazile su takođe na praktičnu obuku. Podmladak Crvenog krsta je dovodio učenice osmog razreda beogradskih gimnazija na kurs na kojem su im lekari i sestre davali teorijske i praktične upute o nezi odojčeta. Krajem 1932. otvoren je jednogodišnji tečaj za negovateljice odojčadi i male dece u trajanju od godinu dana, koji je u ovoj prvog generaciji završilo 19 učenica. One su tokom kursa radile na svim odeljenjima Doma i slušale su predavanja o zdravom i bolesnom odojčetu, njegovoj nezi i ishrani, predavanja iz opšte higijene, higijene žene i porodilje, prve pomoći, zaraznih bolesti, domaćinstva i telesnih vežbi žena i dece. Početkom novembra 1933, kada je primljena druga generacija učenica, napisan je pravilnik za ovaj tečaj, a 1935. u okviru Materinskog udru- 
Ženja formirana je nova sekcija - Sekcija za tečaj negovateljica, koja je vodila evidenciju svršenih učenica, pratila njihov rad na tečaju i kasnije pomagala $u$ zapošljavanju.

Ovaj savremeno opremljen i stručno vođen Dom bio je mesto koje su često posećivale najviše državne, diplomatske i stručne delegacije. Tokom 1926. posetila ga je ledi Aberdin, predsednica Međunarodnog ženskog saveza, kao i grupa lekara Rokfelerove misije. Među uglednim gostima 1928. godine bili su Korbet Ažbi, predsednica i Malater Selije, potpredsednica Internacionalne alijanse za žensko pravo glasa, gđa Ferije član Lige internacionalnog Crvenog krsta, gđa Berg predsednica Nudiljske škole iz Pariza, članovi Pariske opštine i drugi.

Materinsko udruženje je svečano proslavilo 25-godišnjicu rada 28. i 29. decembra 1929. godine. Proslava je otpočeta Blagodaranjem u Vaznesenskoj crkvi kome su prisustvovali predstavnici svih humanitarnih i kulturnih društava, dobrotvori, utemeljitelji, članovi i prijatelji udruženja. Odata je počast preminulim osnivačima dr Jovanu Jovanoviću i predsednicama Sari Karamarković i Dragi Ljočić. Svečana sednica je održana 29. decembra u sali Doma Materinskog udruženja. Dvorska dama i članica udruženja Ela Hadžić je bila predstavnica kraljice Marije, visoke zaštitnice Materinskog udruženja. Prilikom proslave društva odlikovani su: Ordenom Belog orla $\mathrm{V}$ reda Zorka Vlajić i dr Matija Ambrožić, kao i mnoge zaslužne članice društva.

Pravila društva, koja su prvi put napisana i odobrena 1904. godine, menjana su i prilagođavana novonastalim situacijama više puta. Prva izmena je izvršena 1906. godine, a posle rata i stvaranja nove države još dva puta 1922. i 1929. Prema godišnjim izveštajima najveći broj redovnih članica društvo je imalo 1926. čak 649, ali je u kasnijem periodu došlo do smanjenja broja članica, verovatno i zbog, realnim potrebama neprimerenog, enormnog porasta broja novoformiranih dobrotvornih, esnafskih, kulturnih i drugih društava. Pored redovnih članica, dobrotvora i velikih dobrotvora, od 1925. godine uvedena je još jedna vrsta članova - pomažući članovi koji su malim mesečnim prilozima pomagali Materinsko udruženje. Te godine je stvoren i Odbor gospođica Materinskog udruženja koje su najčešće radile na organizaciji zabava i prikupljanju novčanih priloga. Ovo društvo, za razliku od drugih ženskih društava, nije imalo svoje podružnice. Stvoreno je nekoliko Materinskih udruženja po ugledu na beogradsko, ali su ona bila samostalna društva koja nisu zavisila od odluka uprave u Beogradu. Tako je 1926. godine osnovano Materinsko udruženje u Somboru, u Sarajevu 1935, dok je u Bitolju otvorena prihvatna stanica Materinskog udruženja.

Materinsko udruženje je uspešno radilo do početka Drugog svetskog rata. Borba sa predrasudama i materijalnim teškoćama bila je stalna. U međuratnom periodu Materinsko udruženje je ostalo član Jugoslovenskog ženskog saveza, naslednika Srpskog narodnog ženskog saveza, čiji je jedan od osnivača bilo. Zasluge njegovih članica nisu bile samo u očuvanju dečijih života već su se one borile i za poboljšanje položaja žena, aktivno kao i pre rata, a Leposava 
Petković, predsednica Saveza, to je više puta istakla. U međuratnom periodu u Kraljevini SHS i Kraljevini Jugoslaviji nastala su mnoga društva koja su se starala o napuštenoj deci, devojkama i samohranim majkama. To su bila: Dobrotvorno društvo nezaštićena majka i dete, Društvo ,Zaštita devojaka“, Humano društvo „Plemenita duša dečje nade“, Humano društvo „Siroče“ i druga. Uz njih i država je sada vodila više računa o socijalnim pitanjima stvarajući i posebno ministarstvo već 1918. godine - Ministarstvo socijalne politike. Ipak su uloga Materinskog udruženja, a posebno njihovi napori prilikom izgradnje Doma ostavili dubok trag u istoriji socijalne zaštite i unapređenja položaja odojčadi i samohranih majki. U zgradi Doma za odojčad Materinskog udruženja danas se nalazi Institut za neonatologiju.

\section{Zaključak}

Nepostojanje državne socijalne politike u Kraljevini Srbiji podstaklo je ugledne lekare i društvene angažovane, pre svega beogradske, gospođe da svojim angažovanjem pokrenu brojne humanitarne akcije. Jedna od najlepših i najkorisnijih je bila akcija Materinskog udruženja na zbrinjavanju napuštene dece najmlađih uzrasta. Uz njih, ovo društvo je vodilo brigu o napuštenim i bolesnim samohranim majkama. Učešćem u radu društva gotovo svih beogradskih lekarki - dr Drage Ljočić, dr Marije Zibold, dr Ljubice Gođevac, dr Marije Vučetić, dr Marije Savić, omogućena je ovoj deci i njihovim majkama neophodna preventivna zdravstvena zaštita. Velikim angažovanjem u prikupljanju finansijskih sredstava članice društva uspele su da osnuju prvi Dom za nahočad i da ga niz godina izdržavaju uz veliku pomoć državnih organa. Kasnije namenski izgrađen Dom za odojčad bio je dobro opremljen i ispunjavao je najstrože higijenske i zdravstvene uslove. Stručno osoblje su u početku činili lekari koji su radili volonterski uz stalnu pomoć obučenih članica društva, a kasnije su činili i stalno zaposleni lekari i nudilje. Dom je postao moderna, funkcionalna institucija u koju su često dovođene strane delegacije državne, diplomatske i stručne kako bi im se ovaj vid socijalne zaštite dece predstavio u najlepšem svetlu. Drugi značajan aspekt rada Materinskog udruženja ogledao se u podizanju društvene svesti o položaju žene u srpskom društvu. Rušeći društvene stereotipe, hrabro su se borile za promenu pojedinih članova Građanskog zakona. Posebnu pažnju su poklanjale najugroženijim grupama stanovništva - siromašnim i samohranim majkama, odbačenim od porodice i celokupnog društva. Njima su pomagale u najtežim periodima posle porođaja, često ih zapošljavajući u Domu kao dojilje ili im pomažući da nađu odgovarajući posao i smeštaj. Iako je rad ovih društava bio uglavnom ograničen na teritoriju Beograda, zahvaljujući tome što su na vreme zbrinjavale napuštenu i odbačenu decu, članice ovih društava su činile najveće dobročinstvo - spasavale su nedužne živote. 


\section{REFERENCE}

- Almanah humanih društava. Uredili Siniša L. Sretenović i Božidar S. Nedeljković-Ročkoman. Beograd: izdanje urednika, 1940.

- Dom Materinskog udruženja u Beogradu, posvećeno svečanom otvaranju Doma Mat. udruženja 4. decembra 1925. god. Za štampu priredila Dar. Ć. Panić. Beograd: b. i., 1926.

- Godišnji izveštaj Materinskog udruženja (1912-1913, 1925-1939). Beograd: b. i., 1912, 1913, 1925-1939.

- „Godišnji izveštaj uprave Materinskog udruženja za 1907. god.“. Domaćica, organ Ženskog društva i njegovih podružina. God. XXIX, br. 5, (Beograd, maj 1908), 1-21.

- Ivanović, Dragan. Kolevka zdravstva u Srbiji, knj. 1. Ruma: Srpska knjiga, 2003.

- „Izveštaj Materinskog udruženja za 1906. godinu“. Domaćica, organ Ženskog društva i njegovih podružina. God. XXX, br. 5, (Beograd, maj 1907), 1-18.

- Jovanović, Jovan J. „Materinsko udruženje“. Narodno zdravlje, br. 1, (1905).

- „Materinsko udruženje u 1908. godini, godišnji skup držan 30. januara 1909. god.“. Domaćica, organ Ženskog društva i njegovih podružina. God. XXX, br. 2, (Beograd, 1909), 5-12.

- Milanović, Jasmina. „Prva ženska bolnica u Kneževini Srbiji 1876-1877“. U: 800 godina srpske medicine, Treći Sokolski zbornik. Urednik Zoran Vacić, 15-34. Beograd: Srpsko lekarsko društvo, 2017.

- Pravila društva Materinskog udruženja. Beograd: Društvo Materinskog udruženja, 1904.

- Pravila Materinskog udruženja. Beograd: b. i., 1929.

- Spomenica proslave dvadesetpetogodišnjice Materinskog udruženja. Beograd: b. i., 1930.

- Srpkinja, njezin život i rad, njezin kulturni razvitak i njezina narodna umjetnost do danas. Irig: Dobrotvorna zadruga Srpkinja u Irigu, 1913.

- Stojanović, Dubravka. „U senci 'velikih narativa': Stanje zdravlja žena i dece u Srbiji početkom XX veka“. U: Žene $i$ deca, 4. Srbija u modernizacijskim procesima XIX i XX veka. 160-175. Beograd: Helsinški odbor, 2006.

- Veljković, Snežana. Izgubljena bitka dr Drage Ljočić. http://www.rastko. rs/rastko/delo/15022 (pristupljeno 13. 3. 2015). 
JASMINA MILANOVIĆ, PhD, Senior Research Associate

Institute of Contemporary History

Belgrade, Republic of Serbia

jasmina.mil17@gmail.com

\section{MATERNITY SOCIETY - \\ HUMAN AND SOCIAL ASPECTS OF ACTION 1904-1941}

\section{Summary}

Social politics of Principality and Kingdom of Serbia was not organized on a state level, as there was no ministry nor even a department which would systematically tackle any social issues. The care for the poor, the sick and the abandoned was reduced to single acts of mercy, however the municipalities were obliged to take care of abandoned children. The founding of the Maternity Society on the 4th December 1904 marked a beginning of organized care for young, abandoned children. The purpose of this society was to establish a hygienic home for infants and children up to the age of 7 where they could bring up those deprived of parental care. The participation of almost all of Belgrade's women doctors - dr Draga Ljočić, dr Marija Zibold, dr Ljubica Gođevac, dr Marija Vučetić, dr Marija Savić, provided necessary healthcare to these children. With the significant engagement of Maternity Society's members and collection of financial resources, they managed to establish the first Home for Foundlings in 1905/06 and maintain it for many years with great help from state authorities.

The purpose-built Home for Infants, populated in 1925, was well equipped and fulfilled the hygienic and medical regulations. In the beginning, the medical staff consisted of volunteer doctors with constant help from trained Society's members, although later it also included permanently employed doctors and nurses. The Home turned into a modern, functional institution where they brought many foreign state, diplomatic and professional delegations in order to present this form of social help in the best light. Other significant aspects of the Maternity Society were raising social awareness on women's position in Serbian society. Breaking social stereotypes, they bravely fought for changing certain acts of the Civil law. Special attention was given to the most neglected social groups - the poor and single mothers, cast out from their families and the entire society. Society's members helped them in hardest times after they've given birth, often hiring them in the Home as wet nurses or helping them find jobs and accommodation. Although the work of these societies was limited to Belgrade territory, by taking care of abandoned and cast out children, their members did the greatest act of kindness - saving innocent lives.

KEYWORDS: Maternity Society, Sara Karamarković, Draga Ljočić, social politics, Home for Foundlings, Home for Infants 